\title{
The impact of vegetation on sedimentary organic matter composition and PAH desorption
}

\author{
Elizabeth Guthrie Nichols*, Samuel T. Gregory, Jennifer S. Musella \\ North Carolina State University, Department of Forestry and Environmental Resources, 2800 Faucette Drive, Raleigh, NC 27695, USA
}

Plants alter sediment organic matter composition and PAH desorption behavior.

\section{A R T I C L E I N F O}

\section{Article history:}

Received 30 September 2007

Received in revised form 8 May 2008

Accepted 11 May 2008

Available online $\mathrm{xxx}$

\section{Keywords:}

Phragmites

PAHs

Desorption

Sediments

Phytoremediation

\begin{abstract}
A B S T R A C T
Relationships between sedimentary organic matter (SOM) composition and PAH desorption behavior were determined for vegetated and non-vegetated refinery distillate waste sediments. Sediments were fractionated into size, density, and humin fractions and analyzed for their organic matter content. Bulk sediment and humin fractions differed more in organic matter composition than size/density fractions. Vegetated humin and bulk sediments contained more polar organic carbon, black carbon, and modern (plant) carbon than non-vegetated sediment fractions. Desorption kinetics of phenanthrene, pyrene, chrysene, and $\mathrm{C}_{3}$-phenanthrene/anthracenes from humin and bulk sediments were investigated using Tenax ${ }^{\circledR}$ beads and a two-compartment, first-order kinetic model. PAH desorption from distillate waste sediments appeared to be controlled by the slow desorbing fractions of sediment; rate constants were

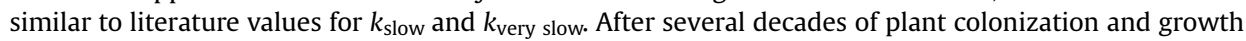
(Phragmites australis), vegetated sediment fractions more extensively desorbed PAHs and had faster desorption kinetics than non-vegetated sediment fractions.
\end{abstract}

(c) 2008 Elsevier Ltd. All rights reserved.

\section{Introduction}

Prior studies indicate that the quality of sedimentary organic matter (SOM), more so than SOM quantity, influences polycyclic aromatic hydrocarbon (PAH) desorption behavior (Oen et al., 2006; Shor et al., 2003). Recent studies have correlated PAH desorption behavior to specific SOM structures such as expanded and condensed amorphous domains (Gunasekara and Xing, 2003), aromatic carbon (Yang et al., 2004), aliphatic carbon (Chefetz et al., 2000; Salloum et al., 2002; Mao et al., 2002), black carbon (Oen et al., 2006; Cornelissen et al., 2005), diagenetically aged carbon (Johnson et al., 2001; Rockne et al., 2002), and SOM polarity (Rutherford et al., 1992; Kile et al., 1999; Xing et al., 1994). PAH desorption from different SOM domains results in disparate desorption behavior that can be described using terminology such as rapidly desorbing, slow desorbing, very slow desorbing, or desorption resistant (Cornelissen et al., 1997; Shor et al., 2003; Jonker et al., 2005; Saffron et al., 2006). Desorption behavior is generally assumed to control PAH bioavailability (Kukkonen et al., 2003) and the success of remedial activities, particularly, bioremediation (Cornelissen et al., 1998) and phytoremediation (Ahn et al., 2005).

Recent studies have focused on diagenetically aged SOM domains, such as coke, coals, and kerogen, and how their structure

\footnotetext{
* Corresponding author. Tel.: +1 919513 4832; fax: +1919 5156193.

E-mail address: elizabeth_nichols@ncsu.edu (E.G. Nichols).
}

influences overall PAH sorption and desorption behavior in sediments (Cornelissen et al., 2005; Yang et al., 2004). Geologically mature geosorbents exhibit large sorptive capacities for PAHs as well as slow or resistant PAH desorption behavior due to diagenetic processes that remove polar functional groups while increasing the condensed, aromatic carbon domains of SOM (Johnson et al., 2001; Gunasekara and Xing, 2003). Less mature geosorbents may exhibit slow or resistant PAH desorption due to condensed, aliphatic carbon domains (Gunasekara and Xing, 2003; Oren and Chefetz, 2005; Chen and Xing, 2005; Salloum et al., 2002). Regardless of the SOM domain, the presence or absence of polar functional groups, or SOM polarity, appears to strongly correlate with PAH desorption behavior (Chen et al., 2005).

The successful application of phytoremediation to sites containing aged and weathered PAHs would benefit from improved mechanistic understanding of how plant-derived organic matter either enhanced PAH desorption or accelerated PAH sequestration and $\mathrm{PAH}$ desorption hysteresis. Indigenous microorganisms are thought to facilitate PAH desorption (Li et al., 2005), and plants typically increase overall microbial abundance, diversity, and activity in SOM due to plant carbon deposition (Binet et al., 2000; Joner et al., 2002; Chen et al., 2003). Root exudates and other plantderived materials can disaggregate or polymerize humic materials important to PAH release and sorption (Gregory et al., 2005).

A few studies have addressed how PAH desorption in fieldcontaminated sediments is affected by diagenetically immature 
materials such as plant organic matter (Rockne et al., 2002; Shor et al., 2003; Kukkonen et al., 2003). Rapidly desorbing fractions of bioavailable PAHs were associated with sediment compartments containing plant pigments, lipids, and lignin (Kukkonen et al., 2003). The authors proposed that these plant materials represented amorphous and less rigid carbon domains that facilitated rapid PAH desorption. Rockne et al. (2002) observed that the mass amounts of desorbed PAH and PAH desorption rates were greater for low density fractions containing coarse plant detritus than heavier sediment fractions. Furthermore, plant detrital sediment fractions appeared to control overall PAH release from whole sediments and were PAHenriched relative to other sediment fractions. These findings have significant implications for phytoremediation of PAHs in soils and sediments where deposition of plant materials is certain to occur.

The purpose of this study was to better understand how longterm exposure to vegetation alters PAH distribution and desorption in refinery, distillate waste sediments relative to sediment organic matter (OM) composition. We used field-contaminated sediments from a site that had naturally re-vegetated over 40 years. This site, a refinery distillate waste pit, was chosen because vegetation had colonized and grown on a well-defined, significant petrogenic PAH source. Prior work determined that PAH concentrations and PAH weathering indices were similar among composite sediment samples collected at three different vegetated areas. PAH concentrations and weathering indices for these vegetated sediments significantly differed from composite non-vegetated sediments (Gregory et al., 2005). Total PAH concentrations and PAH weathering did not differ between established Phragmites areas and two other vegetated sites analyzed. For this reason, composite samples of two sites, the barren, non-vegetated sediments and established Phragmites sediments, were used for PAH desorption studies.

To reduce heterogeneity within weathered, distillate waste sediments, vegetated and non-vegetated composite samples were homogenized further in the laboratory then separated into bulk sediment, 12 size and density fractions, and humin fractions. Fractions were characterized for several chemical parameters to evaluate changes to the distillate waste organic matrix. In addition to total PAH concentrations in sediment fractions, $\mathrm{PAH}$ desorption data were collected for several PAHs including an alkylated PAH homologue in select fractions. We hypothesized different organic matter composition in vegetated sediment fractions would alter $\mathrm{PAH}$ desorption behavior in vegetated sediment fractions relative to non-vegetated sediment fractions.

\section{Materials and methods}

\subsection{Site description}

The study site is a 2-3 acre peat/clay estuary wetland that was used as a distillate waste pit of different gasoline blends, or pitch, at a petroleum refinery facility along the northeastern coast, USA. Phragmites australis, a rhizomatous, semi-aquatic plant, is an invasive reed that has colonized the distillate waste pit over the last 40 years. The distillate waste pit is $\approx 10-15$ feet in depth with $\approx 18 \%$ total petroleum hydrocarbon contamination; the pitch is periodically evident on the surface as tar-like balls. Non-vegetated, barren areas are present due to high salinity content from periodic estuarine salt water intrusion.

\subsection{Sediment sampling and fractionation}

The method for field collection, transport, and storage of composite sediments from the refinery, distillate waste pit has been previously described (Gregory et al. 2005). Briefly, prior to sediment fractionation and desorption studies, field-composited sediments were sieved $(2 \mathrm{~mm})$ then homogenized again in ceramic bowls Because distillate waste pit sediments are impacted by salinity from estuary tides, conductivity measurements of Phragmites and non-vegetated bulk sediments were determined using extracts of sediment/water ratios (Rhoades, 1996) and an YSI Model 85 multi probe meter (Yellow Springs, OH). Aliquots of bulk sediment were freeze-dried, then ground, and chemically fractionated to obtain humin fractions as described in Gregory et al. (2005). Humin fractions were de-ashed with a hydrochloric and hydrofluoric acid mixture as previously described (Gregory et al., 2005). Non-fractionated bulk sediments were size fractionated by wet sieving using sequential sieve sizes from $300 \mu \mathrm{m}$ to $32 \mu \mathrm{m}$ for the following fractions: $<32 \mu \mathrm{m}, 32$ $45 \mu \mathrm{m}, 45-63 \mu \mathrm{m}, 63-150 \mu \mathrm{m}, 150-300 \mu \mathrm{m}$ and $>300 \mu \mathrm{m}$. Particle size fractions were further separated into light and heavy density fractions using a cesium chloride solution with a specific gravity of 1.8 similar to Ghosh et al. (2000).

\subsection{Sedimentary organic matter composition}

Bulk sediment, de-ashed humin, light density, and heavy density fractions were analyzed for black carbon (BC) content by acidification of freeze-dried samples with 1.2 $\mathrm{M}$ hydrogen chloride then thermal oxidation at $375^{\circ} \mathrm{C}$ for $24 \mathrm{~h}$ followed by total organic carbon measurement (Gelinas et al., 2001; Wakeham et al., 2004). Elemental analyses of carbon, hydrogen, and nitrogen were determined by high-temperature combustion and/or pyrolysis techniques on a ConFlo III Elemental Analyzer (Thermo Electron North America LLC, West Palm Beach, FL). One sediment fraction and a set of duplicate sediment fractions, making up $25 \%$ of samples analyzed, were sent to Huffman Labs (Golden, $\mathrm{CO}$ ) for quality assurance and quality control. Standard methods ASTM D-4129 (C and H), ASTM D-5373 (N), and ASTM D-5622 (O) were used. Percent relative standard deviation (RSD) was predominantly within $10 \%$ for most samples. Functional groups in sediment fractions were analyzed by FTIR on an Impact 400 Nicolet (1993) FTIR spectrophotometer equipped with an OMNIC automatic data acquisition system. The sample pellets used were prepared by grinding $0.5-1.0 \mathrm{mg}$ of sediment fraction and $60-80 \mathrm{mg}$ infrared-grade potassium bromide $(\mathrm{KBr})$ salt separately using a mortar and pestle; powdered sediments were mixed with powdered KBR, pressed together, then analyzed. Data acquisition was accomplished by using a 32 spectrum resolution per $\mathrm{cm}$.

\subsection{Desorption experiments}

Salinity content is thought to limit Phragmites colonization of the distillate waste pit, and Table 1 shows that non-vegetated sediments were more saline (higher electrical conductivity measurements) than Phragmites sediments (Table 1, Gregory et al., 2005). Zhao and Pignatello (2004) found that the impact of salinity on PAH uptake by Tenax ${ }^{\circledR}$-TA beads was minor; thus, Tenax was an effective sorbent to trap PAHs from freshwater and seawater environments. PAH desorption was measured in triplicate for seven time points spanning a 120-day period using Tenax beads $(0.15 \mathrm{~g}$ 20-35 mesh, Alltech Associates, Inc. College, PA) in batch isotherm experiments. Five grams of air-dried contaminated sediments were added to $40 \mathrm{~mL}$ of a mercuric chloride $\left(2 \mathrm{~g} / \mathrm{L} ; \mathrm{HgCl}_{2}\right)$ solution in $60 \mathrm{~mL}$ amber glass jar with Teflon coated plastic lids similar to (Zhao and Pignatello, 2004; Oen et al., 2006; Ghosh et al., 2000). Tenax beads were placed into stainless steel baskets (Ted Pella, Inc., Reading, CA) that were

Table 1

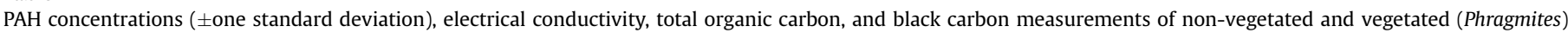
sediment fractions from the distillate waste pit

\begin{tabular}{|c|c|c|c|c|c|c|}
\hline Sediment fraction & Total $\mathrm{PAH}^{\mathrm{a}, \mathrm{b}} \mu \mathrm{g} / \mathrm{g}$ & $\begin{array}{l}\text { Electrical } \\
\text { conductivity } \mu \mathrm{S} / \mathrm{cm}^{\mathrm{a}}\end{array}$ & Organic carbon $^{\mathrm{a}} \mathrm{mg} / \mathrm{g}$ & Organic matter $^{\mathrm{a}, \mathrm{c}} \mathrm{mg} / \mathrm{g}$ & BC carbon $^{\mathrm{a}, \mathrm{d}} \mathrm{mg} / \mathrm{g}$ & $\begin{array}{l}\text { OM to non-soot C } \\
\text { ratio }^{\mathrm{a}, \mathrm{e}} \text { (mass basis) }\end{array}$ \\
\hline \multicolumn{7}{|l|}{ Non-vegetated } \\
\hline Bulk sediment & $161 \pm 11.8$ & $1139 \pm 140$ & $226 \pm 8.32$ & $323 \pm 30.1$ & $28 \pm 4.3$ & $1.6 \pm 0.22$ \\
\hline $\mathrm{HF} / \mathrm{HC} 1$ humin & $6.0 \pm 1.0$ & & $86 \pm 5.4$ & $94 \pm 4.5$ & $65 \pm 0.37$ & $4.0 \pm 0.96$ \\
\hline \multicolumn{7}{|l|}{ Phragmites } \\
\hline Bulk sediment & $69 \pm 2.9$ & $463 \pm 179$ & $271 \pm 2.52$ & $372 \pm 33.7$ & $95 \pm 16$ & $2.0 \pm 0.37$ \\
\hline $\mathrm{HF} / \mathrm{HC} 1$ humin & $2.8 \pm 0.3$ & & $288 \pm 7.50$ & $371 \pm 15.6$ & $188 \pm 19.3$ & $3.9 \pm 0.40$ \\
\hline
\end{tabular}

\footnotetext{
a Average of triplicate measurements \pm one standard deviation.

b Gregory et al. (2005).

c Dry mass loss after heating $\left(375^{\circ} \mathrm{C}, 24 \mathrm{~h}\right)$.

d Organic carbon after heating $\left(375^{\circ} \mathrm{C}, 24 \mathrm{~h}\right)$.

e Ratio of organic matter to non-black carbon organic carbon (TOC-BC).
} 
sealed with a lid and suspended in the jar above sediments by stainless steel wire platforms. Jars were capped, sealed with Teflon ${ }^{\circledR}$ tape, positioned upright on the shaker table to prevent cages from sitting directly in sediment, and allowed to shake for time periods ranging from $24 \mathrm{~h}$ to 120 days. At each time point, jars were removed from the shaker table and baskets were extracted and blotted to capture excess water. Tenax beads were then removed from baskets, placed into $40 \mathrm{~mL}$ amber EPA vials, and extracted twice with $10 \mathrm{~mL}$ of hexane for $30 \mathrm{~min}$. Any water remaining in the hexane was removed using sodium sulfate $\left(\mathrm{Na}_{2} \mathrm{SO}_{4}\right)$. Hexane extracts were evaporated to $<1 \mathrm{~mL}$ under a gentle stream of $\mathrm{N}_{2}$ gas and transferred to GC/MS vials using a $500 \mu \mathrm{L}$ syringe as described above in preparation for GC/MS analysis. After completion of desorption studies, PAH concentrations in sediments were determined as described in Gregory et al. (2005).

\subsection{Gas chromatography/mass spectrometry - select-ion-monitoring}

Phenanthrene, $C_{3}$-alkylated phenanthrenes/anthracenes, pyrene, and chrysene concentrations in sediment fractions and desorption extracts were determined using an HP5890 Series II GC outfitted with electronic pressure control attached to an HP5970 or HP5972 MSD utilizing a Restek $30 \mathrm{~m} \times 0.25 \mathrm{~mm}$ Rtx-5 (film thickness $0.25 \mu \mathrm{m}$ ) MS w/Integra-Guard column. The select-ion-monitoring (SIM) mode was employed (Gregory et al., 2005). Both sediment and desorption extracts were spiked prior to analysis with $50 \mu \mathrm{L}$ of a PAH recovery internal standard (RIS) containing both deuterated phenanthrene- $d_{10}(500 \mathrm{ng} / \mathrm{mL})$ and benzo[ $a$ ]pyrene- $d_{12}(505 \mathrm{ng} / \mathrm{mL})$. Sample extracts were analyzed using a modified method of EPA 8270 (USEPA, 1986) similar to that employed by Luellen and Shea (2002).

\section{6. $\delta^{14} \mathrm{C}$ radiocarbon analyses}

Sediment samples were sent to The Lawrence Livermore National Laboratory (Livermore, CA) for standard radiocarbon dating analysis. Sediment fractions were combusted to $\mathrm{CO}_{2}$ then reacted with a $\mathrm{Fe} / \mathrm{H}_{2}$ catalyst to form graphite. Splits of combusted samples were taken for ${ }^{13} \mathrm{C}$ analysis to correct AMS values (Stuiver and Polach, 1977). Samples were analyzed by AMS with standards (NBS Oxalic Acid I and II (NIST-SRM-4990, 4990c) and blanks for organic carbon samples (Johnson-Mathey 99.9999\% graphite powder)). Data are expressed as the percent modern carbon $\left({ }^{14} \mathrm{C}\right.$ $\mathrm{PMC}$ ) determined from the measurement of fraction modern that is the deviation of the ${ }^{14} \mathrm{C} / \mathrm{C}$ ratio of a sample from "modern" (Stuiver and Polach, 1977). Petroleum contains very little ${ }^{14} \mathrm{C}$ activity $\left({ }^{14} \mathrm{C}\right.$ PMC $\sim 0 \%$ ) because of its ancient origin; whereas, modern plant carbon and recent humification of modern plant carbon will reflect modern ${ }^{14} \mathrm{C}$ activity $\left({ }^{14} \mathrm{C} \mathrm{PMC} \sim 100 \%\right)$ from atmospheric ${ }^{14} \mathrm{CO}_{2}$.

\subsection{Data analysis}

Desorption from sediment can be described by the following two-compartment first-order kinetic model shown in Eq. (1) (Oen et al., 2006; Cornelissen et al., 1997, 1998):

$\frac{S_{t}}{S_{0}}=F_{1} \mathrm{e}^{-k_{1} t}+F_{2} \mathrm{e}^{-k_{2} t}$

$S_{t}$ and $S_{0}$ are the observed sediment-sorbed amounts at time $t$ (days) and at the start of the experiment. $F_{1}$ and $F_{2}$ represent two kinetically different desorbing fractions of the contaminant present in the sediment. The first-order rate constants for rapid and slow desorbing fractions of contaminant are noted as $k_{1}$ and $k_{2}\left(\right.$ days $\left.^{-1}\right)$. One assumption of the model is that $k_{2} \ll k_{1}$. The model was fitted to observed PAH desorption data to estimate rate constants $\left(k_{1}\right.$ and $\left.k_{2}\right)$, faster-desorbing PAH fractions $\left(F_{1}\right)$ and slower-desorbing PAH fractions $\left(F_{2}\right)$ by minimizing the cumulative squared residuals between observed and calculated values of $\ln \left(S_{t} / S_{0}\right)$ in Eq. (1) under the boundary condition that $F_{1}+F_{2}=1$. The best-fit adjustable parameter values were found using the solver function in Microsoft Excel ${ }^{\circledR} 7.0$ (Redmond, WA USA) (Denton, 2000). Concentrations of total and select PAHs between vegetated ( $P$. australis) and non-vegetated sediment fractions (Table 1 ) were compared to determine if vegetation significantly altered PAH concentrations in sediments. Statistical significance was determined using a one-tailed Student's $t$-test $(p<0.05)$ where the mean of a vegetated sediment fraction was compared to a non-vegetated sediment fraction. Correlations between individual PAH concentrations and the distribution ratios of $\log \left(F_{2} / F_{1}\right)$ were determined by linear regression.

\section{Results and discussion}

\subsection{Organic matter composition of sediment size and density fractions}

Sediment mass distribution in size and density sediment analyses did not present significant trends or associations as observed in other studies. In prior studies, the majority of sediment mass $(>75 \%)$ was found among specific size fractions $(<63 \mu \mathrm{m}$ and $63-$ $300 \mu \mathrm{m}$ size fractions) of heavy density fractions (Ghosh et al.,
2000). PAHs were associated with light density fractions that accounted for $<10 \%$ of the sediment mass (Rockne et al., 2002; Ghosh et al., 2000), and black carbon (BC), an important compartment to PAH bioavailability in sediments (Cornelissen et al., 2005), was a significant component of light density fractions (Rockne et al., 2002; Ghosh et al., 2000).

In contrast, we observed that both vegetated (Phragmites) and non-vegetated sediments had similar mass distributions of sediment by size and density (Figure S1a; Supporting Information). The majority of PAHs were associated with light density fractions, but light density fractions represented $32 \%$ and $52 \%$ of the non-vegetated and Phragmites sediment mass, respectively (Figure S1 b \& c; Supporting Information). The BC carbon content of both light and heavy density fractions was similar (Table S1; Supporting Information). PAH weathering ratios indicated little weathering in either light or heavy density fractions between vegetated and nonvegetated fractions (Table S1; Supporting Information).

Vegetated (Phragmites) density fractions contained more plant carbon, as represented by ${ }^{14} \mathrm{C}$ percent modern carbon (PMC) (44\% and $31 \%$, respectively), than non-vegetated density fractions $(2.6 \%$ and $5.3 \%$, respectively). However, the presence of plant carbon did not explain differences in condensed versus oxidized organic matter for light and heavy density fractions (Table S2; Supporting Information). Our results most likely reflect the existence of a dominant source material, the refinery distillate waste. We previously observed that $\mathrm{PAH}$ weathering and organic matter composition were distinctly different between vegetated and non-vegetated bulk sediment and humin fractions (Gregory et al., 2005). Thus, we evaluated the extent and rate of PAH desorption from bulk sediment and humin fractions to determine if observed differences in OM composition altered PAH desorption behavior in vegetated and non-vegetated sediment fractions.

\subsection{Organic matter composition of bulk sediment and humin fractions}

We previously observed that vegetated (Phragmites) bulk sediment and humin had significantly reduced total PAH concentrations, more weathered PAH ratios (Table 1; Student's t-test, $p<0.05$ ), significantly greater organic carbon content, and greater ${ }^{14} \mathrm{C}$ percent modern carbon content than non-vegetated, distillate waste sediment fractions (Table 2; Student's t-test, $p<0.05$ ) (Gregory et al., 2005). Additional analyses reported in this study showed that the black carbon (BC) content ( $\mathrm{mg} \mathrm{BC} / \mathrm{g}$ sediment) was also greater in vegetated fractions than non-vegetated sediment fractions (Table 1). Elemental analyses and atomic ratios $(\mathrm{H} / \mathrm{C}$ and $\mathrm{O} / \mathrm{C}$ ) indicated that vegetated fractions were more oxidized and less condensed than non-vegetated fractions; this difference was particularly apparent for vegetated humin fractions (Table 2).

The relative importance of Phragmites carbon deposition to sediment and humin composition is even more apparent in the polarity index (PI) calculations (Table 2) derived from the elemental data (Table S3, Supporting Information). The polarity index is the weight ratio of O + N to C (Rutherford et al., 1992; Xing et al., 1994); it has been used to describe the degree of SOM condensation, to determine polar/non-polar composition of SOM fractions, and to predict PAH sorption to SOM fractions (Huang and Weber, 1997; Chen et al., 2005; Mao et al., 2002; Kang and Xing, 2005). The polarity indices for Phragmites bulk sediment and humin were significantly greater than their non-vegetated counterparts (Student's $t$-test, $p<0.05$ ), but, polarity differences between non-vegetated and vegetated humin were even more distinct than observed between bulk sediments (Table 2). FTIR data likewise supports these observed differences between vegetated and non-vegetated sediment (Figure S2, Supporting Information). For example, the presence of polar functionalities, such as the increased $\mathrm{O}-\mathrm{H}$ 
Table 2

Organic matter composition and desorption rate parameters for four PAHs in sediment fractions from non-vegetated and Phragmites sediment fractions

\begin{tabular}{|c|c|c|c|c|c|c|c|c|c|c|c|c|}
\hline & & \multicolumn{5}{|c|}{ Bulk sediment } & & \multicolumn{5}{|c|}{ De-ashed humin } \\
\hline & & \multicolumn{3}{|c|}{ Non-vegetated (mean $\pm \mathrm{SD}$ ) } & \multicolumn{3}{|c|}{ Phragmites (mean $\pm \mathrm{SD}$ ) } & \multicolumn{3}{|c|}{ Non-vegetated (mean \pm SD) } & \multicolumn{2}{|c|}{ Phragmites (mean $\pm \mathrm{SD}$ ) } \\
\hline \multicolumn{2}{|c|}{$\overline{\text { Atomic } \mathrm{H} / \mathrm{C}^{\mathrm{a}}}$} & \multicolumn{2}{|c|}{$0.1 \pm 0.000$} & & \multicolumn{2}{|c|}{$0.1 \pm 0.02$} & & \multicolumn{2}{|c|}{$0.03 \pm 0.003$} & & \multicolumn{2}{|c|}{$0.07 \pm 0.01$} \\
\hline & \multicolumn{2}{|c|}{$0.3 \pm 0.01$} & & \multicolumn{2}{|c|}{$0.4 \pm 0.01$} & & \multicolumn{2}{|c|}{$0.1 \pm 0.004$} & & \multicolumn{2}{|c|}{$0.3 \pm 0.06$} \\
\hline \multicolumn{2}{|c|}{$\%$ Polarity index ${ }^{\mathrm{b}}$} & \multicolumn{2}{|c|}{$35 \pm 0.70$} & & \multicolumn{2}{|c|}{$44 \pm 2.2$} & & \multicolumn{2}{|c|}{$13 \pm 0.40$} & & \multicolumn{2}{|c|}{$37 \pm 6.04$} \\
\hline$\%$ Modern & & $2 \pm$ & & & \multirow{2}{*}{\multicolumn{2}{|c|}{$\begin{array}{l}24 \pm 0.16 \\
27 \pm 0.25\end{array}$}} & & \multirow{2}{*}{\multicolumn{2}{|c|}{$\begin{array}{l}2 \pm 0.08 \\
9 \pm 0.54\end{array}$}} & & \multirow{2}{*}{\multicolumn{2}{|c|}{$\begin{array}{l}33 \pm 0.20 \\
29 \pm 0.75\end{array}$}} \\
\hline \multicolumn{2}{|c|}{$\%$ Organic $C^{a, c}$} & \multicolumn{2}{|c|}{$\begin{array}{r}2 \pm 0.00 \\
23 \pm 0.83\end{array}$} & & & & & & & & & \\
\hline & $\begin{array}{l}F_{1} \\
\left(10^{-3}\right)^{\mathrm{e}}\end{array}$ & $\begin{array}{l}k_{1} \\
\left(\text { day }^{-1}\right)^{\mathrm{f}}\end{array}$ & $\begin{array}{l}k_{2} \\
\left(10^{-4} / \text { day }\right)^{\mathrm{f}}\end{array}$ & $\begin{array}{l}F_{1} \\
\left(10^{-3}\right)^{\mathrm{e}}\end{array}$ & $\begin{array}{l}k_{1} \\
\left(\text { day }^{-1}\right)^{\mathrm{f}}\end{array}$ & $\begin{array}{l}k_{2} \\
\left(10^{-4} / \text { day }\right)^{\mathrm{f}}\end{array}$ & $\begin{array}{l}F_{1} \\
\left(10^{-3}\right)^{\mathrm{e}}\end{array}$ & $\begin{array}{l}k_{1} \\
\left(\text { day }^{-1}\right)^{\mathrm{f}}\end{array}$ & $\begin{array}{l}k_{2} \\
\left(10^{-4} / \text { day }\right)^{\mathrm{f}}\end{array}$ & $\begin{array}{l}F_{1} \\
\left(10^{-3}\right)^{\mathrm{e}}\end{array}$ & $\begin{array}{l}k_{1} \\
\left(\text { day }^{-1}\right)^{\mathrm{f}}\end{array}$ & $\begin{array}{l}k_{2} \\
\left(10^{-4} / \text { day }\right)^{\mathrm{f}}\end{array}$ \\
\hline Phen & 3.8 & 0.76 & 1.5 & 5.3 & 0.76 & 1.9 & 124 & 0.35 & 33 & 173 & 0.32 & 69 \\
\hline$C_{3}$-Phene ${ }^{d}$ & 1.1 & 0.76 & 0.64 & 1.9 & 0.76 & 1.2 & 124 & 0.34 & 33 & 99 & 0.15 & 60 \\
\hline Pyrene & 0.68 & 0.76 & 0.93 & 3.4 & 0.76 & 1.8 & $<0.01$ & 0.023 & 149 & 245 & 0.58 & 125 \\
\hline Chrysene & 1.1 & 0.76 & 0.64 & 3.0 & 0.76 & 0.87 & 64 & 2.2 & 62 & 125 & 0.52 & 39 \\
\hline
\end{tabular}

a Values are means of triplicates \pm one standard deviation.

b Polarity Index $=(\mathrm{O}+\mathrm{N}) / \mathrm{C}$ (see SI Table 1$)$; values are duplicates \pm one standard deviation.

c Gregory et al. (2005).

d $C_{3}$-phenethrene/anrthracenes.

e Rapidly desorbing fraction of sediment $F_{1}$.

${ }^{\mathrm{f}}$ Rate constants for more rapid $\left(k_{1}\right)$ and slower $\left(k_{2}\right)$ desorbing fractions of each PAH in sediment fraction.

stretching of carboxylic $\mathrm{C}(-\mathrm{COOH})$ at $3400 \mathrm{~cm}^{-1}$ and $\mathrm{C}-\mathrm{O}$ stretching for polysaccharides at 1157,1087 , and $1049 \mathrm{~cm}^{-1}$, is apparent in Phragmites sediment humin (Yang et al., 2004; Chen et al., 2005). Prior OM content analysis by ${ }^{13} \mathrm{C}$ nuclear magnetic resonance (NMR) detected the emergence of O-alkyl carbon in Phragmites humin (Gregory et al., 2005) whereas chemical shifts in this region were absent for non-vegetated humin.

Black carbon (BC) is an important sediment compartment to PAH sequestration, desorption, and bioavailability; typically, BC comprises $1-20 \%$ (median of $9 \%$ ) of the total organic carbon present in sediment (Cornelissen et al., 2005). Observed BC and OM to non-soot $C$ ratios measurements for non-vegetated bulk sediments $(13 \% \pm 1.8)$ were similar to other $\mathrm{BC}$ measurements of estuarine sediments near to our study area (Rockne et al., 2002). But, \% BC content of vegetated bulk sediment (35\%) and both humin fractions (73\% and 66\%) were greater than non-vegetated bulk sediment. Large soot/BC content (32\% and 56\%) were observed by Rockne et al., 2002 for select estuarine sediment fractions containing plant detrital material near to our field site. The large BC measurements for our humin fractions may represent changes to humin by the chemical fractionation procedure used to obtain fractioned-ashed humin. Humin is obtained by alkaline extraction (sodium hydroxide) and several organic solvent extractions (dichloromethane) of the bulk sediment that removes lipid-soluble organic matter. Thus, the humin material used for desorption isotherms in this study had a large proportion of organic matter removed by humic fractionation prior to BC analysis.

Collectively, the organic, black, and plant carbon content of vegetated (Phragmites) sediment and humin differed from nonvegetated bulk sediment and humin (Table 2). Increases in non-BC organic carbon and modern carbon content, particularly for vegetated humin fractions, appears related to increased OM polarity and oxidized OM that would result from the presence of diagenetically immature plant materials. Prior studies have observed that increases in OM polarity and oxidation decrease the sorption of organic contaminants, particularly PAHs, to OM (Rutherford et al., 1992; Xing et al., 1994; Kile et al., 1999) and reduce apparent sorption-desorption hysteresis. One might predict that PAH desorption from more polar, oxidized matrices should be greater than PAH desorption from more nonpolar, reduced OM matrices (Huang and Weber, 1997; Johnson et al., 2001; Wang et al., 2005). We measured the extent and rate of PAH desorption from bulk sediment and humin fractions to determine if observed differences in OM composition altered PAH partitioning and desorption behavior in vegetated and non-vegetated sediment fractions.

\subsection{PAH desorption}

Non-vegetated sediments desorbed more pyrene and chrysene, cumulative mass (ng/g), than vegetated sediments; the cumulative, desorbed mass of $C_{3}$-phenanthrene and phenanthrene was similar for all sediment fractions (Table 3). The extent of PAH desorption was greater for all PAHs in vegetated bulk sediment (Table 3 ). The extent of PAH desorption is defined as the total cumulative $\mathrm{PAH}$ desorbed in 120 days divided by the total sediment PAH concentration. Thus, a greater fraction of PAH was available to desorb from vegetated bulk sediments than non-vegetated bulk sediments.

Nearly $80 \%$ of the PAHs present in humin were desorbed relative to less than $3 \%$ desorbed from bulk sediments. Interestingly, more pyrene, chrysene, and $C_{3}$-phenanthrene desorbed from humin than phenanthrene (Table 3). The lower extent of desorption for less hydrophobic PAHs relative to more hydrophobic PAHs has been previously observed and is attributed to the release or degradation of lower molecular weight PAHs in highly weathered sediments (Oen et al., 2006; Shor et al., 2003). Vegetated (Phragmites) humin more extensively desorbed phenanthrene and $C_{3}$-phenanthrene than non-vegetated humin (Student's $t$-test; $p<0.05$ ); whereas, the extent of desorption for chrysene and pyrene was not different for humin fractions (Table 3; Student's $t$-test, $p<0.05$ ).

When data were normalized to the total PAH desorbed as a function of time (Figure S3, See Supporting Information), vegetated humin desorbed pyrene and chrysene faster although similar fractions of PAH were desorbed (Table 3). Fifty percent of pyrene and chrysene was desorbed between 20-30 days in Phragmites humin versus 40-50 days for non-vegetated humin. These findings are similar to prior studies (Rockne et al., 2002) that observed more extensive and rapid PAH desorption from sediment fractions containing coarse, nonporous plant detrital material relative to sediments without plant detrital matter present.

\subsection{Desorption rate constants and desorbing fractions}

To better evaluate differences in rates of $\mathrm{PAH}$ desorption between vegetated and non-vegetated sediment fractions, rate constants for PAH desorption from fast and slow PAH desorbingsediment compartments were calculated using Eq. (1). The observed fractional desorption data for bulk sediments (Fig. 1) and humin (Fig. 2) of each PAH show a decrease in slope that indicates a more rapid then slower phase of $\mathrm{PAH}$ release over time. The solid 
Table 3

Mean values of PAH concentrations, cumulative mass PAH desorbed (Tenax ${ }^{\circledR}, 120$ days), and percent PAH desorbed of total extractable PAH for sediment ${ }^{\mathrm{a}}$

\begin{tabular}{|c|c|c|c|c|}
\hline Fractions & & Total $\mathrm{PAH}^{\mathrm{b}} \pm \mathrm{SD}(\mu \mathrm{g} / \mathrm{g})$ & $\begin{array}{l}\text { Cumulative mass } \\
\text { desorbed } \pm \mathrm{SD}(\mathrm{ng} / \mathrm{g})\end{array}$ & $\begin{array}{l}\text { Extent desorbed } \\
\text { of total } \mathrm{PAH} \pm \mathrm{SD}(\%)\end{array}$ \\
\hline \multicolumn{5}{|l|}{ Phenanthrene } \\
\hline Non-vegetated & Bulk sediment & $1.1 \pm 0.41$ & $25 \pm 1.4$ & $2.3 \pm 0.13$ \\
\hline Phragmites & Bulk sediment & $1.0 \pm 0.02$ & $29 \pm 2.4$ & $2.8 \pm 0.23$ \\
\hline Non-vegetated & Humin & $0.26 \pm 0.099$ & $108 \pm 4.97$ & $42 \pm 1.9$ \\
\hline Phragmites & Humin & $0.18 \pm 0.052$ & $115 \pm 10.4$ & $65 \pm 5.9$ \\
\hline \multicolumn{5}{|l|}{ Pyrene } \\
\hline Non-vegetated & Bulk sediment & $6.0 \pm 0.96$ & $72 \pm 11$ & $1.2 \pm 0.18$ \\
\hline Phragmites & Bulk sediment & $1.5 \pm 0.22$ & $42 \pm 5.3$ & $2.7 \pm 0.34$ \\
\hline Non-vegetated & Humin & $0.42 \pm 0.013$ & $405 \pm 12.6$ & $97 \pm 3.01$ \\
\hline Phragmites & Humin & $0.20 \pm 0.009$ & $181 \pm 15.3$ & $90 \pm 7.6$ \\
\hline \multicolumn{5}{|l|}{ Chrysene } \\
\hline Non-vegetated & Bulk sediment & $4.0 \pm 0.41$ & $34 \pm 2.9$ & $0.8 \pm 0.07$ \\
\hline Phragmites & Bulk sediment & $1.4 \pm 0.12$ & $19 \pm 1.0$ & $1.3 \pm 0.068$ \\
\hline Non-vegetated & Humin & $0.16 \pm 0.0074$ & $151 \pm 4.10$ & $95 \pm 2.6$ \\
\hline Phragmites & Humin & $0.09 \pm 0.01$ & $87 \pm 6.5$ & $95 \pm 7.1$ \\
\hline \multicolumn{5}{|l|}{$C_{3}$-phenanthrene } \\
\hline Non-vegetated & Bulk sediment & $6.9 \pm 0.23$ & $65 \pm 5.5$ & $0.9 \pm 0.1$ \\
\hline Phragmites & Bulk sediment & $2.3 \pm 0.47$ & $42 \pm 4.0$ & $1.8 \pm 0.17$ \\
\hline Non-vegetated & Humin & $0.15 \pm 0.041$ & $108 \pm 5.10$ & $72 \pm 3.4$ \\
\hline Phragmites & Humin & $0.12 \pm 0.022$ & $109 \pm 7.33$ & $90 \pm 6.1$ \\
\hline
\end{tabular}

a Values represent mean \pm one standard deviation (SD) $(n=3)$.

b Total extractable PAH in sediment fraction.

data points in Figs. 1 and 2 represent means of observed desorption measurements ( $n=3$; \pm one standard deviation) at specific time points over 120 days. Lines were obtained by exponential curve fitting and represent calculated values using the empirical, firstorder, two-compartment model described in Eq. (1). Fitting the observed data to Eq. ( 1$)$ provides rate constants $\left(k_{1}\right.$ and $\left.k_{2}\right)$ and the two PAH desorbing-sediment compartments $\left(F_{1}\right.$ and $\left.F_{2}\right)$ as shown in Table 2.

Comparison of desorption rate constants between non-vegetated and vegetated sediment fractions shows that (1) PAHs desorbed faster from humin fractions than bulk sediments for both non-vegetated and vegetated sediments and (2) PAHs desorbed faster from vegetated (Phragmites) sediment fractions than non- vegetated sediment fractions (Table 2) except for pyrene and chrysene in humin. Faster desorption rate constants $\left(k_{1}\right)$ were on the order of $10^{-1}$ /day for bulk sediments and $10^{-1}$ to $10^{-2}$ /day for humin fractions. Slower desorption rate constants $\left(k_{2}\right)$ were on the order of $10^{-4}$ to $10^{-5} /$ day for bulk sediments and $10^{-2}$ to $10^{-3}$ /day for humin fractions.

Our observed slower rate constants $\left(k_{2}\right)$ are similar to other long-term slow desorption rate constants $\left(10^{-3} /\right.$ day) (Kan et al., 2000). Translating our data to rate constants $\left(\mathrm{h}^{-1}\right)$ yielded rate constants for bulk sediment that ranged from $10^{-2} / \mathrm{h}$ for "faster" or $k_{1}$ to $10^{-6} / \mathrm{h}$ to $10^{-5} / \mathrm{h}$ for "slower" or $k_{2}$. Rate constants for humin ranged from $10^{-2} / \mathrm{h}$ for "faster" or $k_{1}$ to $10^{-4} / \mathrm{h}$ for "slower" or $k_{2}$. Average rate constants for PAH desorption from natural sediments
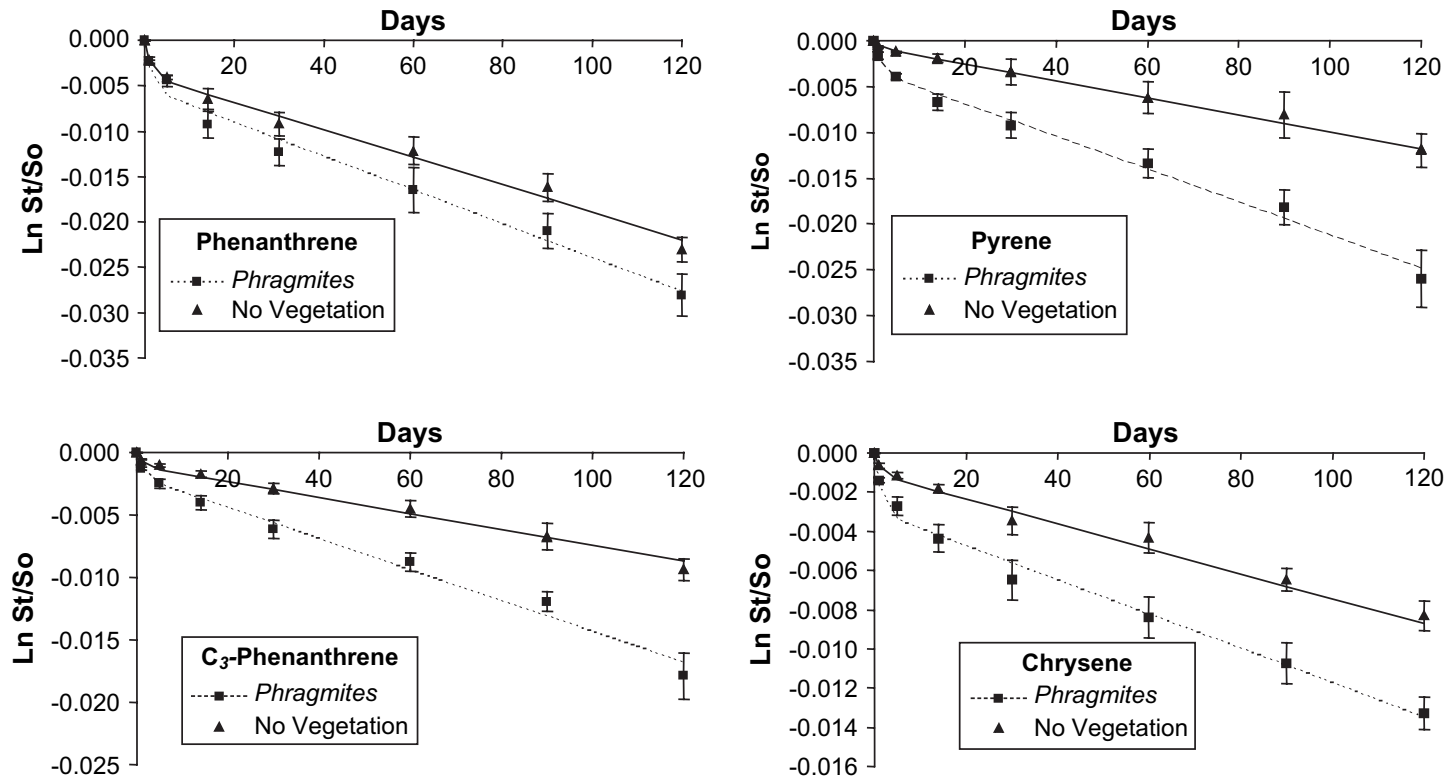

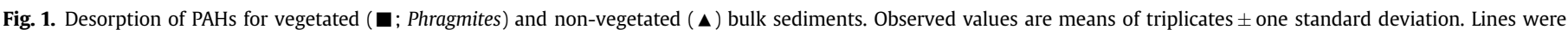

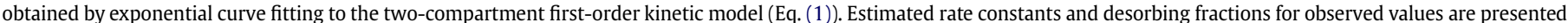
in Table 2.

Please cite this article in press as: Elizabeth Guthrie Nichols et al., The impact of vegetation on sedimentary organic matter composition and PAH desorption, Environ. Pollut. (2008), doi:10.1016/j.envpol.2008.05.011 

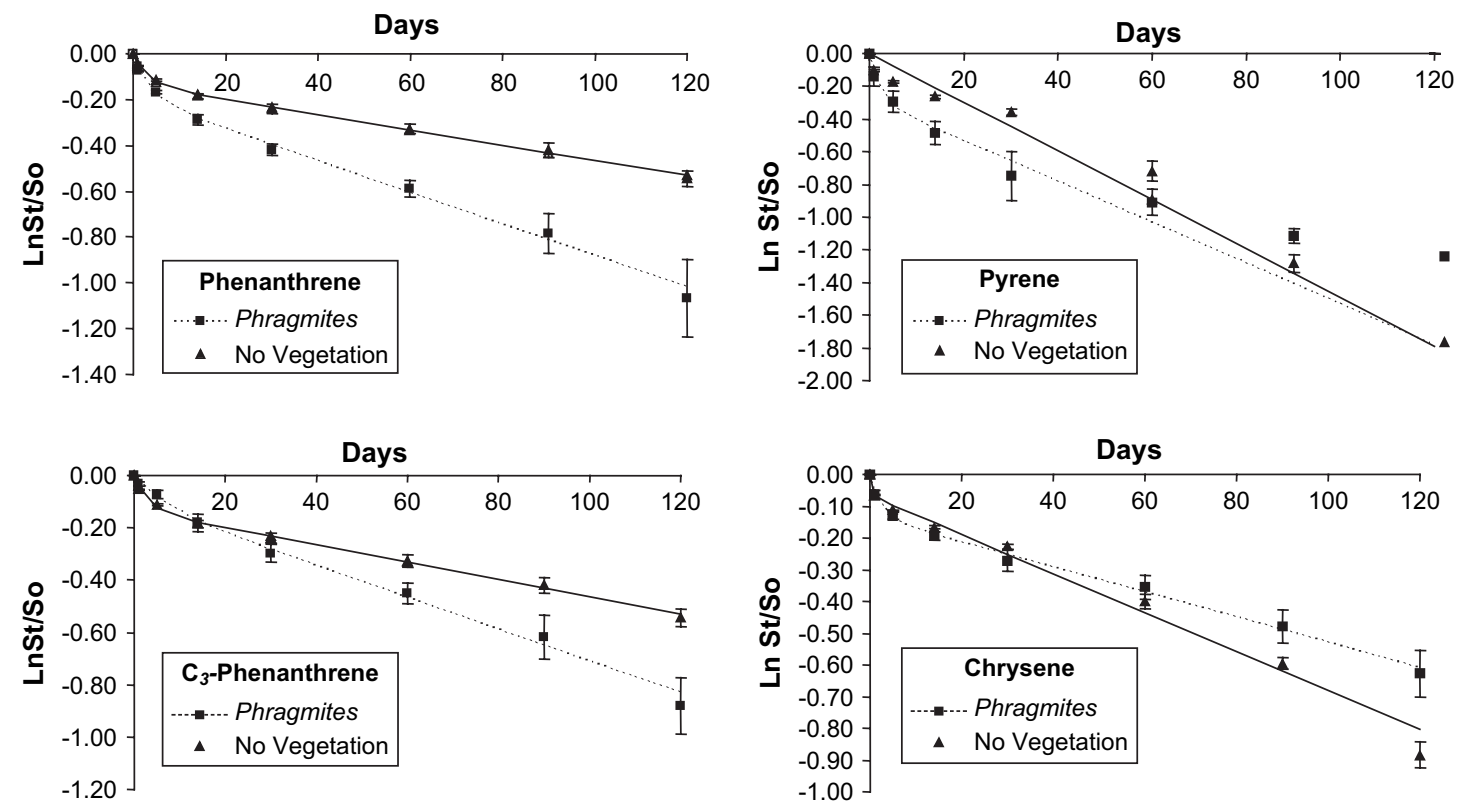

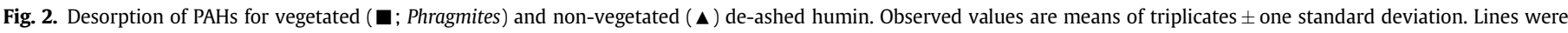

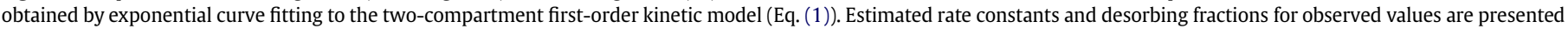
in Table 2.

ranges from $10^{-1}$ to $10^{-0} / \mathrm{h}$ for "fast", $10^{-3}$ to $10^{-2} / \mathrm{h}$ for "slow", and $10^{-5}$ to $10^{-4} / \mathrm{h}$ for "very slow" (Johnson et al., 2001; Jonker et al., 2005; Oen et al., 2006). Our observed rate constants suggest that distillate waste sediments do not contain fast desorbing fractions. Instead, PAH desorption is controlled by the slow desorbing fractions of sediment; rate constants for $k_{1}$ and $k_{2}$ reflect literature values more similar to $k_{\text {slow }}$ and $k_{\text {very slow. Differences between }}$ desorption behavior of these sediments and literature values may result from the source of PAH contamination (distillate waste), organic matter composition (Johnson et al., 2001), and weathering (Oen et al., 2006).

The sediment compartment that controls more rapid release of PAHs $\left(F_{1}\right)$ was greater in vegetated sediments fractions than nonvegetated fractions (Table 2 ). Thus, faster desorption rate constants and greater faster-desorbing fraction values were observed for vegetated sediments. Vegetated fractions contained lower individual PAH (Table 3) and total PAH (Table 2) concentrations. Linear regression of individual $\mathrm{PAH}$ concentrations to their respective desorbing fractions, $\log \left(F_{2} / F_{1}\right)$, was used to evaluate if different PAH concentrations between vegetated and non-vegetated sediment fractions were associated with PAH desorption behavior (Fig. 3). For bulk sediments, slower desorption was associated with greater PAH concentrations $\left(r^{2}=0.71\right)$. For humin, desorption behavior and PAH concentrations did not appear correlated to each other $\left(r^{2}=0.094\right)$. Oen et al. (2006) observed no correlation $\left(r^{2}<0.02\right)$ to weak correlations $\left(r^{2}<0.29 ; p<0.01\right)$ between phenanthrene and pyrene desorption and total PAH concentrations for sediments from three different Norwegian harbors.

Oen et al. (2006) also observed poor correlations between desorption and total organic carbon content. Other studies have observed that quantity of organic matter is a poor predictor for desorption (Shor et al., 2003; Oen et al., 2006; Kukkonen et al., 2003; Cornelissen et al., 2005) relative to other sediment characteristics. Significant correlations have been observed between desorption and either particle size or the black carbon content of sediments.

Black carbon content is thought to control PAH desorption and retard PAH release and bioavailability (Cornelissen et al., 2005). Our observed $\mathrm{BC}$ and $\mathrm{OM}$ to non-soot $\mathrm{C}$ ratios measurements for nonvegetated bulk sediments $(13 \% \pm 1.8)$ were similar to other $\mathrm{BC}$ measurements of estuarine sediments near to our study area (Rockne et al., 2002), but BC content of vegetated sediment fractions were significantly greater than non-vegetated sediment
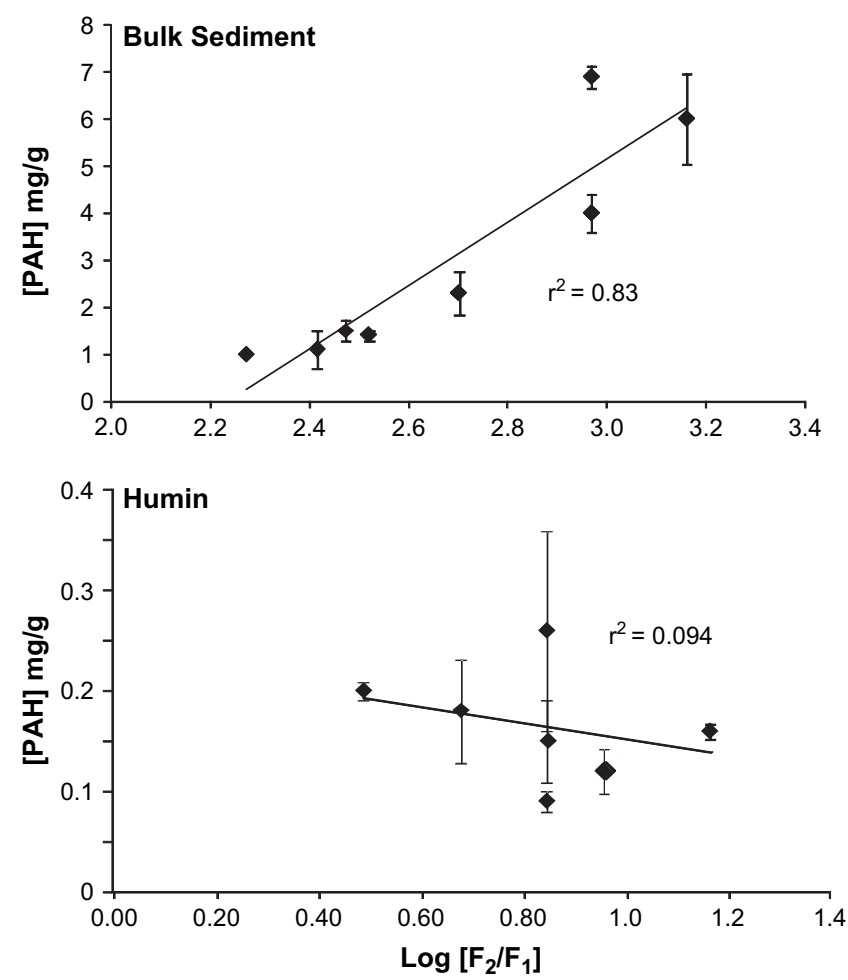

Fig. 3. Simple linear regression of individual PAH concentrations for phenanthrene, pyrene, chrysene, and $C_{3}$-phenanthrenes to the distribution ratio of the slower desorption compartment to the faster desorption compartment $\left(\log \left(F_{2} / F_{1}\right)\right)$ in each sediment fraction. 
fractions (Student's t-test, $p<0.05$ ). Interestingly, increased desorption rate constants were observed for vegetated sediment fractions with greater $\mathrm{BC}$ content. In our study, greater BC content did not appear to slow PAH release as evident in PAH desorption data for either vegetated or non-vegetated humin.

Vegetated sediment fractions, particularly vegetated humin, were more polar, contained more plant carbon, and more organic matter than non-vegetated sediment fractions (Tables 1 and 2); they also desorbed PAHs faster even though they contained greater BC content than non-vegetated fractions. Johnson et al. (2001) hypothesized that geosorbents containing less rigid, labile humic organic matter would allow for faster and more complete $\mathrm{PAH}$ desorption than more condensed, reduced geosorbents such as kerogen. Shor et al. (2003) observed that PAHs rapidly diffused through sediment fractions rich in vascular plant debris and $\mathrm{BC}$ content (Shor et al., 2003), and Rockne et al. (2002) concluded that plant detrital material was more important to PAH sorption/desorption kinetics than $\mathrm{BC}$ content for estuarine sediments with significant plant carbon influx. Kukkonen et al. (2003) observed that the size of the faster desorption compartments $\left(F_{1}\right)$ was directly related to the amount of plant pigment per amount of organic carbon. Thus, immature, young OM increases the $F_{1}$ compartment that controls rapid desorption and the most bioavailable $\mathrm{PAH}$ fraction (Kukkonen et al., 2003; Cornelissen et al., 1998). Based on our analyses of sediment composition and desorption behavior, decadal growth of Phragmites and deposition of plant $\mathrm{C}$ into distillate waste appears related to increased PAH release from both labile (bulk sediment) and more refractory (humin) sediment organic matter.

\section{Conclusions}

Plant organic matter deposition is integral to establishing the "rhizosphere," a zone of influence in vegetated SOM that typically has greater microbial diversity and abundance (Chen et al., 2003) than non-vegetated areas. P. australis is known for its translocation of oxygen and carbon from plant shoots/leaves to sediments via its roots (Minchinton, 2002). The majority of its biomass is non-grazed and nearly $50 \%$ of its litter becomes substrate material for soils and sediments (Asaeda et al., 2002). Observed differences in PAH desorption from bulk sediment and humin fractions may reflect the impact of sediment properties on fast and slow-domain PAH diffusivity through sediment matrices (Shor et al., 2003) altered by the influx of Phragmites organic matter.

The "biology" of phytoremediation is often the primary mechanism used to explain PAH attenuation in soils and sediments. This study emphasized the broader chemical and physical impact of plant organic matter on contaminated OM composition and $\mathrm{PAH}$ bioavailability. We conceptualize that diagenetically, immature plant materials can accumulate in petrogenic sediment OM over time and alter PAH desorption from sediment. Additional studies need to determine whether such changes require decades to occur or may be evident before observed changes to PAH attenuation. Quite possibly, these changes to OM composition and PAH desorption may be observed before significant declines in PAH concentrations are measurable. Shor et al. (2003) found that a $24 \mathrm{~h}$ desorbed fraction of 11 PAHs best represented that fraction of total sediment contamination that was readily desorbed and bioavailable in sediments with and without plant detrital material. Such rapid characterizations may be useful to monitoring the early phases of phytoremediation.

\section{Acknowledgments}

We thank Pete Lazaro, Carter Reeb, John Fountain, and Neal Blair for their assistance with sample analyses. This work was supported with research funding from The National Science Foundation BES-0337453.

\section{Appendix A. Supplementary data}

Supplementary data associated with this article can be found, in the online version, at doi:doi:10.1016/j.envpol.2008.05.011.

\section{References}

Ahn, S.A., Werner, D., Luthy, R.G., 2005. Physicochemical characterization of cokeplant soil for the assessment of polycyclic aromatic hydrocarbon availability and the feasibility of phytoremediation. Environmental Toxicology and Chemistry 24, 2185-2195.

Asaeda, T., Nam, L., Hietz, P., Tanaka, N., Karunaratne, S., 2002. Seasonal fluctuations in live and dead biomass of Phragmites australis as described by a growth and decomposition model, implications of duration of aerobic conditions for litter mineralization and sedimentation. Aquatic Botany 73, 223-239.

Binet, P., Portal, J., Leyval, C., 2000. Dissipation of 3-6 ring polycyclic aromatic hydrocarbons in the rhizosphere of ryegrass. Soil Biology and Biochemistry 32, 2011-2017.

Chefetz, B., Deshmukh, A.P., Hatcher, P.G., Guthrie, E.A., 2000. Pyrene sorption by natural organic matter. Environmental Science and Technology 34, 2925-2930.

Chen, B., Johnson, E.J., Chefetz, B., Zhu, L., Xing, B., 2005. Sorption of polar and nonpolar aromatic organic contaminants by plant cuticular materials, role of polarity and accessibility. Environmental Science and Technology 39, 61386146.

Chen, B., Xing, B., 2005. Sorption and conformational characteristics of reconstituted plant cuticular waxes on montmorillonite. Environmental Science and Technology 39, 8315-8323.

Chen, U.C., Banks, M.K., Schwab, A.P., 2003. Pyrene degradation in the rhizosphere of tall fescue (Festuca arundinacea) and switchgrass (Panicum virgatum L.). Environmental Science and Technology 37, 5778-5782.

Cornelissen, G., Gustafsson, O., Bucheli, T.D., Jonker, M.T.O., Koelmans, A.A., van Noort, P.C.M., 2005. Extensive sorption of organic compounds to black carbon, coal, and kerogen in sediments and soils: mechanisms and consequences for distribution, bioaccumulation, and biodegradation. Environmental Science and Technology 39, 6881-6895.

Cornelissen, G., Rigterink, H., Ferdinandy, M.M.A., van Noort, P.C.M., 1998. Rapidly desorbing fractions of PAHs in contaminated sediments as a predictor of the extent of bioremediation. Environmental Science and Technology 32, 966-970.

Cornelissen, G., van Noort, P.C.M., Govers, H.A.J., 1997. Desorption kinetics of chlorobenzenes, polycyclic aromatic hydrocarbons, and polychlorinated biphenyls: sediment extraction with Tenax ${ }^{\circledR}$ and effects of contact time and solute hydrophobicity. Environmental Toxicology and Chemistry 16, 1351-1357.

Denton, P., 2000. Analysis of first-order kinetics using microsoft Excel Solver. Journal of Chemical Education 77, 1524-1525.

Gelinas, Y., Prentice, K.M., Baldcock, J.A., Hedges, J.I., 2001. An Improved thermal oxidation method for the quantification of soot/graphitic black carbon in sediments and soils. Environmental Science and Technology 35, 3519-3525.

Ghosh, U., Gillette, J.S., Luthy, R.G., Zare, R.N., 2000. Microscale location, characterization, and association of polycyclic aromatic hydrocarbons on harbor sediment particles. Environmental Science and Technology 34, 1729-1736.

Gregory, S.T., Shea, D., Nichols, E.G., 2005. The impact of vegetation on sedimentary organic matter composition and PAH attenuation. Environmental Science and Technology 39, 5285-5292.

Gunasekara, A.S., Xing, B., 2003. Sorption and desorption of naphthalene by soil organic matter, importance of aromatic and aliphatic components. Journal of Environmental Quality 32, 240-246.

Huang, W., Weber, W.L., 1997. A distributed reactivity model for sorption by soils and sediments. 10. Relationships between desorption, hysteresis, and the chemical characteristics of organic domains. Environmental Science and Technology 31, 2562-2569.

Johnson, M.D., Huang, W., Weber Jr., W.J., 2001. A distributed reactivity model for sorption by soils and sediments. 13. Simulated diagenesis of natural sediment organic matter and its impact on sorption/desorption equilibria. Environmental Science and Technology 35, 1680-1687.

Joner, E., Corgie, S., Amellal, N., Leyval, C., 2002. Nutritional constraints to degradation of polycyclic aromatic hydrocarbons in a simulated rhizosphere. Soil Biology and Biochemistry 34, 859-864.

Jonker, M.T.O., Hawthorne, S.B., Koelmans, A.A., 2005. Extremely slowly desorbing polycyclic aromatic hydrocarbons from soot and soot-like materials, evidenced by supercritical fluid extraction. Environmental Science and Technology 39, 7889-7895.

Kan, A.T., Chen, W., Tomson, M.B., 2000. Desorption kinetics of neutral hydrophobic organic compounds from field contaminated sediment. Environmental Pollution 108, 81-89.

Kang, S., Xing, B., 2005. Phenanthrene sorption to sequentially extracted soil humic acids and humins. Environmental Science and Technology 39, 134-140.

Kile, D.E., Wershaw, R.L., Chiou, C.T., 1999. Correlation of soil and sediment organic matter polarity to aqueous sorption of nonionic compounds. Environmental Science and Technology 33, 2053-2056. 
Kukkonen, J.V.K., Landrum, P.F., Mitra, S., Gossiaux, D.C., Gunnarsson, J., Weston, D., 2003. Sediment characteristics affecting desorption kinetics of select PAH and PCB congeners for seven laboratory spiked sediments. Environmental Science and Technology 37, 4656-4663.

Li, J., Pignatello, J.J., Smets, B.F., Grasso, D., Monserrate, E., 2005. Bench-scale evaluation of in situ bioremediation strategies for soil at a former manufactured gas plant site. Environmental Toxicology and Chemistry 24, 741-749.

Luellen, D., Shea, D., 2002. Calibration and field verification of semipermeable membrane devices for measuring polycyclic aromatic hydrocarbons in water. Environmental Science and Technology 36, 1791-1797.

Mao, J.D., Hundal, L.S., Thompson, M.L., Schmidt-Rohr, K., 2002. Correlation of poly(methylene)-rich amorphous aliphatic domains in humic substances with sorption of a nonpolar organic contaminant, phenanthrene. Environmental Science and Technology 36, 929-936.

Minchinton, T., 2002. Disturbance by wrack facilitates spread of Phragmites australis in a coastal marsh. Journal of Experimental Marine Biology and Ecology 281, 89-107.

Oen, A.M.P., Breedveld, G.D., Kalaitzidis, S., Christanis, K., Cornelissen, G., 2006. How quality and quantity of organic matter affect polycyclic aromatic hydrocarbon desorption from Norwegian harbor sediments. Environmental Toxicology and Chemistry 25, 1258-1267.

Oren, A., Chefetz, B., 2005. Sorption-desorption behavior of polycyclic aromatic hydrocarbons in upstream and downstream river sediments. Chemosphere 61, 19-29.

Rhoades, J.D., 1996. Salinity: electrical conductivity and total dissolved solids. In: Bartels, J.M., Bigham, J.M. (Eds.), Methods of Soil Analysis, Part 3, Chemical Methods. Soil Science Society of America and American Society of Agronomy, Madison, Wisconsin, USA.

Rockne, K.J., Shor, L.M., Young, L.Y., Taghon, G.L., Kosson, D.S., 2002. Distributed sequestration and release of PAHs in weathered sediment: the role of sediment structure and organic carbon properties. Environmental Science and Technology $36,2636-2644$.
Rutherford, D.W., Chiou, C.T., Kile, D.E., 1992. Influence of soil organic matter composition on the partition of organic compounds. Environmental Science and Technology 26, 336-340.

Saffron, C.M., Park, J.H., Dale, B.E., Voice, T.C., 2006. Kinetics of contaminant desorption from soil: comparison of model formulations using the Akaike information criterion. Environmental Science and Technology 40, 7662-7667.

Salloum, M., Chefetz, B., Hatcher, P.G., 2002. Phenanthrene sorption by aliphaticrich natural organic matter. Environmental Science and Technology 36, 19531958.

Shor, L.M., Rockne, K.J., Taghon, G.L., Young, L.Y., Kosson, D.S., 2003. Desorption kinetics for field-aged polycyclic aromatic hydrocarbons from sediments. Environmental Science and Technology 37, 1535-1544.

Stuiver, M., Polach, H.A., 1977. Discussion: reporting of ${ }^{14} \mathrm{C}$ data. Radiocarbon 19 , 355-363.

USEPA, 1986. SW-846 Manual for Waste Testing, Volumes 1B and 1C. United States Environmental Protection Agency, Washington, D.C., USA.

Wakeham, S.G., Forrest, J., Masiello, C., Gelinas, Y., Alexander, C.R., Leavitt, P.R., 2004 Hydrocarbons in Lake Washington sediments. A 25-year retrospective in an urban lake. Environmental Science and Technology 38, 431-439.

Wang, X., Sato, T., Xing, B., 2005. Sorption and displacement of pyrene in soils and sediments. Environmental Science and Technology 39, 8712-8718.

Xing, B., McGill, W.B., Dudas, M.J., 1994. Cross-correlation of polarity curves to predict partition coefficients of nonionic organic contaminants. Environmental Science and Technology 28, 1929-1933.

Yang, C., Huang, W., Xiao, B., Yu, Z., Peng, P., Fu, J., Sheng, G., 2004. Intercorrelations among degree of geochemical alterations, physicochemical properties, and organic sorption equilibria of kerogen. Environmental Science and Technology 38, 4396-4408.

Zhao, D., Pignatello, J.J., 2004. Model-aided characterization of Tenax ${ }^{\circledR}$-TA for aromatic compound uptake from water. Environmental Toxicology and Chemistry 23, 1592-1599. 